Article

\title{
Source Material and Concentration of Wildfire-Produced Pyrogenic Carbon Influence Post-Fire Soil Nutrient Dynamics
}

\author{
Lucas A. Michelotti * and Jessica R. Miesel \\ Department of Forestry, Michigan State University, 480 Wilson Road Room 126, East Lansing, \\ MI 48824, USA; E-Mail: mieselje@msu.edu \\ * Author to whom correspondence should be addressed; E-Mail: michel44@msu.edu; \\ Tel.: +1-517-355-8239; Fax: +1-517-432-1143.
}

Academic Editor: Jianbang Gan

Received: 28 February 2015 / Accepted: 13 April 2015 / Published: 21 April 2015

\begin{abstract}
Pyrogenic carbon (PyC) is produced by the thermal decomposition of organic matter in the absence of oxygen $(\mathrm{O})$. PyC affects nutrient availability, may enhance post-fire nitrogen $(\mathrm{N})$ mineralization rates, and can be a significant carbon (C) pool in fire-prone ecosystems. Our objectives were to characterize PyC produced by wildfires and examine the influence that contrasting types of $\mathrm{PyC}$ have on $\mathrm{C}$ and $\mathrm{N}$ mineralization rates. We determined $\mathrm{C}, \mathrm{N}, \mathrm{O}$, and hydrogen $(\mathrm{H})$ concentrations and atomic ratios of charred bark (BK), charred pine cones (PC), and charred woody debris (WD) using elemental analysis. We also incubated soil amended with $\mathrm{BK}, \mathrm{PC}$, and WD at two concentrations for 60 days to measure $\mathrm{C}$ and $\mathrm{N}$ mineralization rates. $\mathrm{PC}$ had greater $\mathrm{H} / \mathrm{C}$ and $\mathrm{O} / \mathrm{C}$ ratios than $\mathrm{BK}$ and WD, suggesting that $\mathrm{PC}$ may have a lesser aromatic component than $\mathrm{BK}$ and WD. $\mathrm{C}$ and $\mathrm{N}$ mineralization rates decreased with increasing $\mathrm{PyC}$ concentrations, and control samples produced more $\mathrm{CO}_{2}$ than soils amended with PyC. Soils with PC produced greater $\mathrm{CO}_{2}$ and had lower $\mathrm{N}$ mineralization rates than soils with $\mathrm{BK}$ or WD. These results demonstrate that $\mathrm{PyC}$ type and concentration have potential to impact nutrient dynamics and $\mathrm{C}$ flux to the atmosphere in post-fire forest soils.
\end{abstract}

Keywords: pyrogenic carbon; black carbon; nitrogen; soil respiration; N mineralization; wildfire; Pinus banksiana 


\section{Introduction}

Wildfire frequency, severity, and fuel availability are predicted to increase in many areas of the world as a result of global climate change [1,2]. Wildfires may exacerbate climate change by releasing carbon dioxide $\left(\mathrm{CO}_{2}\right)$ via the combustion of organic matter during fires and via post-fire microbial decomposition of plants killed by fire. However, pyrogenic carbon (PyC, also known as black carbon) is produced during the thermal decomposition of organic matter in the absence of oxygen $(\mathrm{O})$ (i.e., pyrolysis) and may represent an important carbon (C) pool in fire-affected forests [3-5]. PyC is composed of a labile and soluble component, and an aromatic component [6]. Thus, PyC inputs to soils from forest fires have the potential to influence overall soil respiration rates. PyC has been shown to have a positive priming effect on soil respiration in the short-term, as the labile component is utilized, but PyC may also have a long-term negative priming effect due to the aromatic component [7]. By decreasing soil respiration rates, $\mathrm{PyC}$ addition may promote $\mathrm{C}$ sequestration in forest soil [3,8]. PyC can also affect $\mathrm{N}$ dynamics in forests. For example, wildfires produce ammonium during the burning of biomass, and increase nitrification because they remove vegetation that compete with nitrifying bacteria [9]. However, PyC can increase nitrogen $(\mathrm{N})$ mineralization rates [10] and interact physically with organic compounds that may affect $\mathrm{N}$ cycling [11]. PyC is produced from various source materials and at differing temperatures within individual wildfires [12,13], yet the current scientific understanding of how variation in PyC influences post-fire $\mathrm{C}$ and $\mathrm{N}$ ecosystem dynamics is limited.

Variation in PyC characteristics is influenced by both charring conditions and source material $[3,4,14-16]$. The structure of $\mathrm{PyC}$ is a function of its charring conditions, in which an increase in temperature results in greater overall aromaticity $[4,15,16]$. The number of $\mathrm{O}$ - and $\mathrm{H}$ - containing functional groups that are important for biological degradability decreases continuously as the source material becomes more charred [14]. Furthermore, the interaction of charring temperature and source material influences the ultimate characteristics of the PyC $[3,15]$. Current knowledge of the chemical and physical characteristics of PyC produced by wildfire (hereafter, wildfire $\mathrm{PyC}$ ) is primarily from studies investigating the properties of $\mathrm{PyC}$ produced experimentally (hereafter, experimental PyC) $[3,17]$. Therefore, there is limited understanding of how charring conditions during wildfires influence PyC characteristics produced from various source materials, or how variations in PyC characteristics affect post-fire nutrient dynamics.

Experimental PyC (including biochar) is produced by pyrolysis similar to wildfire PyC, however, charring conditions and source material are held constant during the formation of experimental PyC. In contrast, wildfire $\mathrm{PyC}$ is produced under fluctuating conditions of temperature, heating duration, and oxygen availability during wildfires and originates from mixed sources of organic matter, including standing live or dead trees (with bark, woody tissue, foliage, and seed-bearing structures such as cones), shrubs, herbaceous vegetation, forest litter (dead foliage, bark, and other plant components) and dead woody debris on the forest floor (hereafter, woody debris). These source materials experience different fire environments depending on their physical location within a forest, such as being located at the base of standing trees or in the forest canopy. Thus, experimental PyC may not be representative of the range of wildfire $\mathrm{PyC}$ that occurs in natural fire-prone forest ecosystems [18] because of the differences in charring conditions and source materials that exist between experimental PyC and wildfire PyC. The few studies that have investigated variability in wildfire PyC have found large 
variability in the degree of aromatic condensation, likely due to variation in source material and temperature $[13,18]$. These potential differences in PyC characteristics may influence the extent to which PyC addition to soil alters soil respiration rates and stimulates gross $\mathrm{N}$ mineralization rates (i.e., indices of microbial activity) [3,4,7], with important implications for post-fire nutrient dynamics in soils and ultimately $\mathrm{C}$ sequestration rates by the recovering forest. Here we present data on a suite of major types of wildfire PyC produced in a high-severity, stand-replacing wildfire in jack pine (Pinus banksiana Lamb.) forest in the northern lower peninsula of Michigan, USA. Our overarching objective was to characterize the $\mathrm{PyC}$ produced from major contrasting types of aboveground source material (bark, pine cones, and woody debris) during wildfire in a fire-dependent forest type, and to identify effects on microbially-mediated post-fire nitrogen $\mathrm{C}$ and $\mathrm{N}$ cycling after fire. Our specific objectives were to (1) characterize PyC produced by wildfires and (2) examine the influence that contrasting types and concentrations of PyC have on soil $\mathrm{C}$ and $\mathrm{N}$ mineralization rates. We hypothesized that the addition of PyC to soils would decrease soil respiration and increase $\mathrm{N}$ mineralization, and that the extent to which this occurs would depend on the type and concentration of wildfire PyC.

\section{Experimental Section}

\subsection{Study Site and Sample Collection}

Our study was focused in jack pine forests in Michigan. These forests are primarily monocultures of even-aged jack pine trees. Jack pine is an ecologically similar species to the widespread lodgepole pine ( $P$. contorta Douglas ex Loudon) in the western US. These two closely related species are also major components of boreal forest ecosystems. The fire regime for jack pine forests in our study region is high-severity (i.e., stand-replacing) fires (Figure S1) with a fire return interval of approximately 31 years [19]. Fires may become increasingly severe in many forest types as the climate continues to warm $[20,21]$. Thus, we used a stand-replacing fire in jack pine forest to represent PyC produced in high-severity fire and its effect on forest ecosystem function.

We collected our samples in autumn 2013 from the stand-replacing Howes Lake wildfire. The Howes Lake wildfire was ignited by lightning and lasted from 7 June to 8 June 2011. The fire burned a

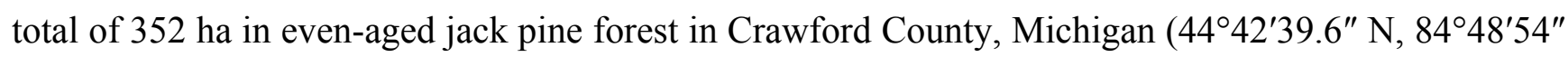
$\mathrm{W})$. The total amount of precipitation between the wildfire and the time of sample collection was 226 $\mathrm{cm}$ [22]. This forest is dominated by jack pine with a minor component of Quercus alba L., Q. velutina Lam., and Q. ellipsoidalis E.J. Hill intermixed. The understory consists of Arctostaphylos uva-ursi (L.) Spreng., Vaccinium angustifolium Aiton, Carex pensylvanica Lam., Schizachyrium scoparium (Michx.) Nash, and Andropogon gerardii Vitman. Soils are classified as sandy Entisols following the USDA soil classification system, which is related to the World Reference Base Arenosol. Specifically, the soil in our study area predominantly represents the Grayling series (Typic Udipsamments), which is characterized by excessively drained, acid, relatively undeveloped medium to medium-fine sand [23]. The Graycalm series (Lamellic Udipsamments) occurs intermixed with the Grayling series and is characterized by the presence of thin, fine-textured bands of loamy sand to sandy clay loam in the lower horizons. The mean annual temperature is $6.7^{\circ} \mathrm{C}$ and the average temperature during the growing season (May through September) is $16.9^{\circ} \mathrm{C}$ [22]. 
We collected three types of wildfire PyC (Figure 1): charred bark (BK), charred pine cones (PC), and charred woody debris (WD). The charred bark was collected from the stem of standing dead jack pine trees, from ground level to $1.37 \mathrm{~m}$. We collected WD from ground level that was between 1.3 and $10.8 \mathrm{~cm}$ in diameter. We collected only WD pieces without bark and with evidence of charred stemwood, which together indicate that the woody debris was dead and on the ground surface before and during the fire. We collected the PC from tree limbs on the soil surface that retained charred bark.
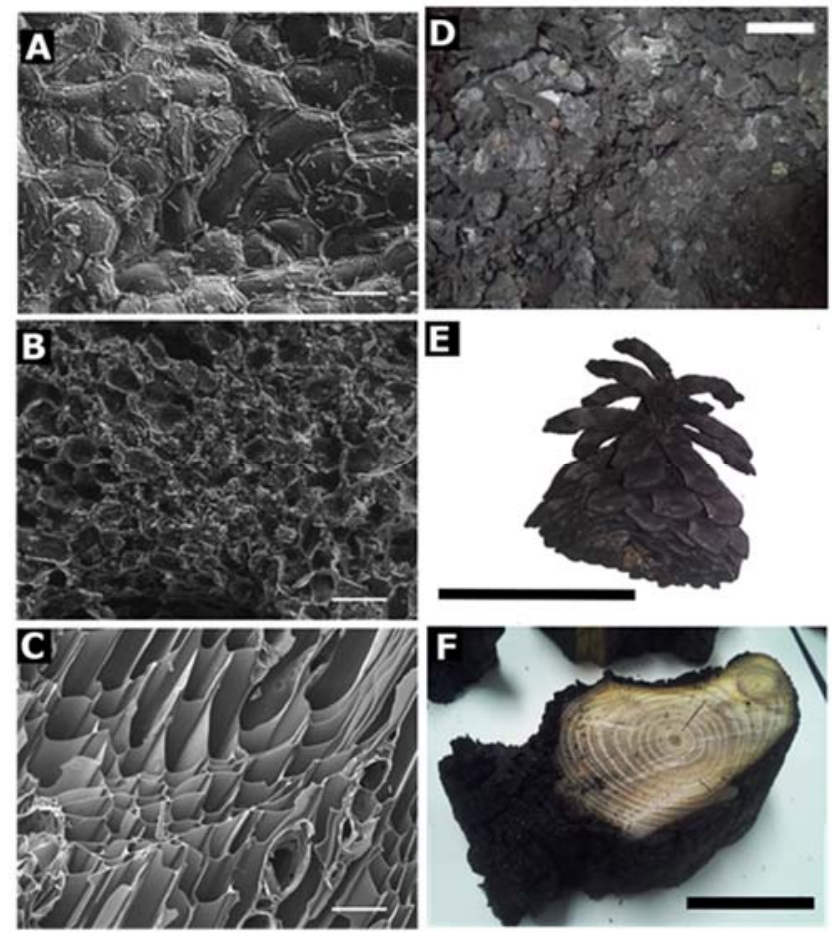

Figure 1. Scanning electron microscopy (SEM) images of charred bark (A), charred pine cones $(\mathbf{B})$, and charred woody debris $(\mathbf{C})$. Scale bars for the SEM images $=50 \mu \mathrm{m}$. Photos to the right of the SEM images (D-F) are images of the corresponding charred material. Scale bar for images shown in panels $\mathrm{D}, \mathrm{E}$ and $\mathrm{F}=4 \mathrm{~cm}$.

The presence of charred bark on the limbs indicates that the pine cones were charred in the forest canopy on trees that were alive at the time of the fire and that fell after the fire. BK and PC were each composited in the field, whereas WD was returned to the lab as individual pieces, from which all blackened material was removed manually from each piece using a small steel plane (Microplane, Grace Manufacturing, Inc., Russellville, AR, USA). From the unburned jack pine forest of the same age outside the Howes Lake fire perimeter, we collected uncharred bark from standing dead trees, and uncharred woody debris and pine cones from the ground surface. The uncharred material was collected to test that differences in chemical composition between the charred materials was due to charring and not simply due to the difference chemical composition of the source material. Because the properties of freshly-produced char can differ from aged char [24,25], we focused on naturally aged PyC collected two years after fire. This approach provides information that is most relevant to understanding relatively persistent effects of wildfire PyC on soil processes in a recovering forest, rather than very short-term impacts that may result from transient chemical characteristics of fresh PyC. 


\subsection{Laboratory Analysis}

We oven-dried all materials at $60{ }^{\circ} \mathrm{C}$ until constant mass. We composited the $\mathrm{BK}$ material by mixing all of the BK that was collected from various trees and we composited the PC material by mixing all of the pine cones that were collected. The WD was processed and retained as individual samples. For charred and uncharred bark, pine cones, and woody debris, we pulverized a subsample to fine powder and determined the weight percent $\mathrm{C}, \mathrm{N}$, hydrogen $(\mathrm{H})$, and oxygen $(\mathrm{O})$ with an elemental analyzer at Atlantic Microlabs (Norcross, GA). We determined percent ash following ASTM E1755-01 [26] and calculated element ratios following established methods [27,28]. We measured pH with a 1:2 w/v ratio of PyC:water [29] using pulverized PyC material.

\subsection{Laboratory Incubations}

We established a 60-day laboratory incubation using a full factorial design of the three types of wildfire PyC and two concentrations of wildfire PyC (1\% and $0.1 \%$ of soil mass, hereafter high and low concentrations, respectively). We followed Deluca, et al. [10] to identify our lowest PyC concentration. Although Deluca, et al. [10] investigated soils from ponderosa pine (Pinus ponderosa Lawson and C. Lawson), there have been no estimates of PyC concentrations in jack pine forest mineral soils to date. We implemented our high concentration as $10 \times$ base PyC concentration to evaluate potential impacts of greater amounts of $\mathrm{PyC}$ addition to soil, which may occur in forests that experience an increase in fire frequency or severity. We used three replicates per treatment per time point (Table S1). Each type of wildfire PyC was ground and passed through a $1.0 \mathrm{~mm}$ sieve in order to homogenize the particle size. We incorporated each type and level of wildfire PyC into field moist mineral soil collected from an unburned area within the same soil classification adjacent to the perimeter of the Howes Lake fire to create a homogenized $300 \mathrm{~g}$ stock media of soil and wildfire PyC for each treatment. The field-moist soil was collected from $0-15 \mathrm{~cm}$ depth and had a $\mathrm{pH}$ of $4.7 \pm 0.0$ and $\mathrm{C}$ and $\mathrm{N}$ concentrations of $1.13 \% \pm 0.04 \%$ and $0.05 \% \pm 0.00 \%$, respectively $(N=2$ replicates of composited soil). For each treatment we used $20.0 \mathrm{~g}( \pm 0.1 \mathrm{~g})$ of stock soil for each sample. The soils were incubated in the dark at constant ambient temperature $\left(25^{\circ} \mathrm{C}\right)$.

We measured $\mathrm{CO}_{2}$ concentrations using a LiCOR LI-820 (Lincoln, NE, USA) on days 10, 20, 40, and $60\left(\mathrm{~T}_{10}, \mathrm{~T}_{20}, \mathrm{~T}_{40}\right.$, and $\mathrm{T}_{60}$, respectively) of the incubation [29]. The samples were sealed for 10 days for $\mathrm{T}_{10}$ and $\mathrm{T}_{20}$, and for 20 days for $\mathrm{T}_{40}$ and $\mathrm{T}_{60}$. The headspace of each sample was flushed with ambient air after each $\mathrm{CO}_{2}$ measurement. On days 0, 20, 40, and 60, three replicates of each treatment combination $(10.0 \pm 0.01 \mathrm{~g}$ each) were extracted with $50 \mathrm{ml} 2 \mathrm{M}$ potassium chloride $(\mathrm{KCl})$, to determine changes in ammonium $\left(\mathrm{NH}_{4}{ }^{+}\right)$, nitrate $\left(\mathrm{NO}_{3}{ }^{-}\right)$, and total inorganic $\mathrm{N}$ concentrations over time, and $\mathrm{N}$ mineralization rates over the 60-day period [29]. $\mathrm{NH}_{4}{ }^{+}$concentrations were measured in accordance to Sinsabaugh, et al. [30], such that the $\mathrm{KCl}$ extracts, ammonia cyanuarte, and ammonia salicylate were mixed in microplate wells and incubated at room temperature for 20 minutes. $\mathrm{NO}_{3}{ }^{-}$ concentrations were measured in accordance to Doane and Horwath [31], such that the $\mathrm{KCl}$ extracts and a saturated vanadium solution were mixed in microplate wells and incubated in the dark at room temperature for 5 hours. After incubation, the microplates were read on a BioTek ELX808 (Winooski, VT, USA) reader at $595 \mathrm{~nm}$. 


\subsection{Statistical Analysis}

We used a Pearson's Correlation test to determine if the elemental composition of the uncharred material was a significant covariate for the charred material. We used an ANOVA (C, percent ash, $\mathrm{O} / \mathrm{C}$, and $\mathrm{H} / \mathrm{C})$, and an ANCOVA with uncharred material as a covariate $(\mathrm{N}, \mathrm{H}$, and $\mathrm{O}$ ) to identify statistically significant differences among the wildfire PyC type using R 3.0.2. We analyzed $\mathrm{C}$ and $\mathrm{N}$ mineralization rates from the incubations using repeated measures ANOVA in SAS 9.3 (SAS Institute, Cary, NC, USA) with PROC MIXED. We used Tukey's adjustment for multiple comparisons to identify statistically significant differences among treatment means and time points. We considered differences to be statistically significant at $p<0.05$.

\section{Results}

\subsection{Chemical Composition}

Using the Pearson's Correlation test, we determined that the elemental composition of the uncharred material was a significant covariate for $\mathrm{H}, \mathrm{N}$, and $\mathrm{O} . \mathrm{H} / \mathrm{C}$ and $\mathrm{O} / \mathrm{C}$ ratios can be used to indirectly measure the aromaticity of a substance [32] and a van Krevelen plot (Figure 2) is a convenient way to visualize the difference in these two ratios between the samples. PC was less aromatic than $\mathrm{BK}$ and $\mathrm{WD}$, as indicated by the ratios of $\mathrm{C}, \mathrm{H}$, and $\mathrm{O}$ (Figure 1 and Table 1). The $\mathrm{O} / \mathrm{C}$ ratio and $\mathrm{H} / \mathrm{C}$ ratio for $\mathrm{PC}$ were $24 \%$ and $25 \%$ greater than $\mathrm{WD}$, respectively, and $12 \%$ and $39 \%$ greater than $\mathrm{BK}$ (Table 1). The $\mathrm{H}$ concentrations and mineral component ( $\%$ ash) were $12 \%$ and $83 \%$ greater in PC than WD, respectively. In addition, PC had 79\% more ash than BK. However, PC had $18 \%$ and $14 \%$ less $\mathrm{C}$ than $\mathrm{WD}$ and $\mathrm{BK}$, respectively. Lastly, the $\mathrm{C} / \mathrm{N}$ ratio in $\mathrm{PC}$ was $60 \%$ lower than in $\mathrm{WD}$. The $\mathrm{C} / \mathrm{N}$ ratio of $\mathrm{BK}$ was $27 \%$ greater than $\mathrm{WD}$.

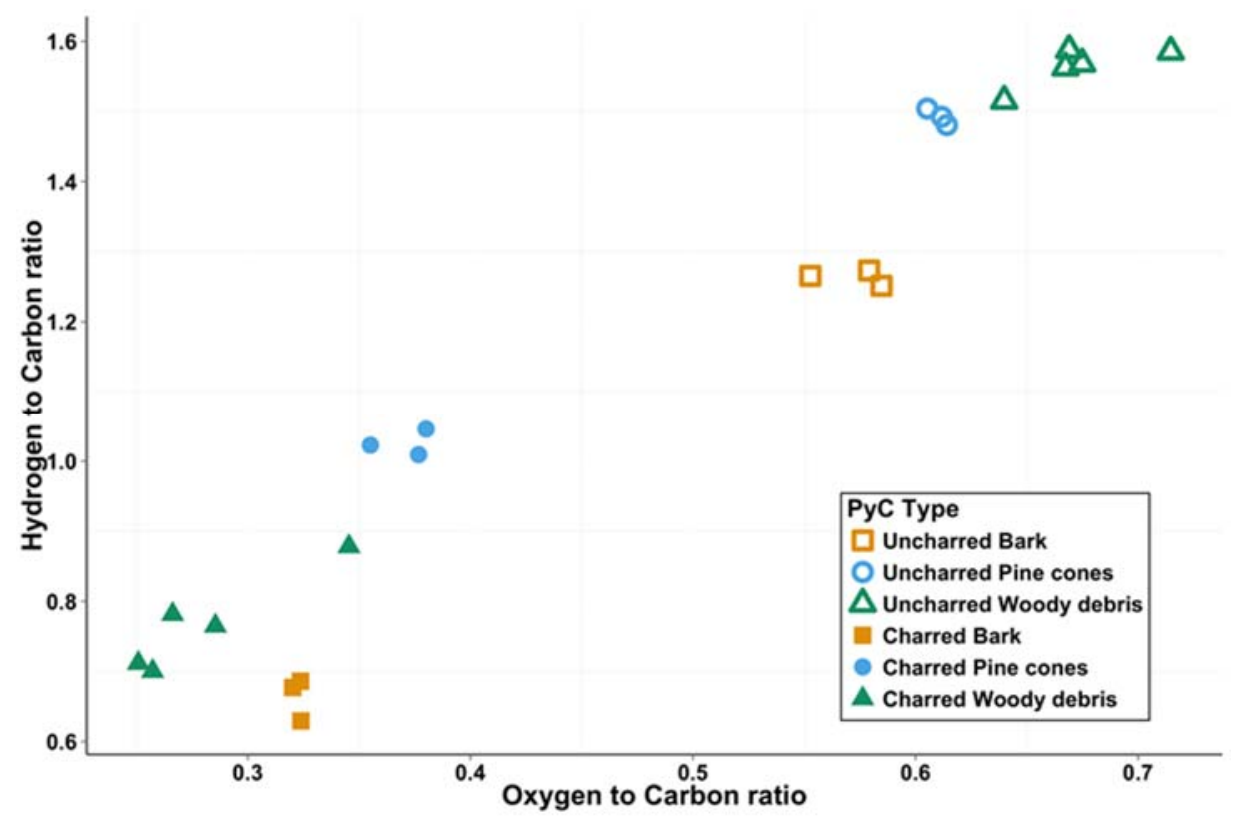

Figure 2. Van Krevelen diagram of uncharred and charred (open and filled symbols, respectfully) bark (yellow), charred pine cones (blue), and charred woody debris (green). The ratios on the axes are expressed as atomic percent of the elements. 
Table 1. Summary table of the mean and standard error (one standard error) of the chemical composition and atomic ratios of charred bark (BK), charred pine cones (PC), charred woody debris (WD), uncharred bark, uncharred pine cones, and uncharred woody debris.

\begin{tabular}{|c|c|c|c|c|c|c|c|c|c|c|}
\hline Material & $n$ & $\% \mathrm{C}$ & $\% \mathbf{H} *$ & $\% \mathbf{N} *$ & $\%$ & $\% A s h$ & $\mathbf{O} / \mathrm{C}$ & $\mathbf{H} / \mathbf{C}$ & $\mathbf{C} / \mathbf{N} *$ & pH \\
\hline \multicolumn{11}{|l|}{ Charred } \\
\hline BK & 3 & $50.22 \pm 0.43 \mathbf{a}$ & $33.34 \pm 0.60 \mathbf{a b}$ & $0.23 \pm 0.01 \mathbf{a}$ & $16.20 \pm 0.17 \mathbf{a}$ & $1.40 \pm 0.19 \mathbf{a b}$ & $0.32 \pm 0.00 \mathbf{a b}$ & $0.66 \pm 0.018 \mathbf{b}$ & $214.97 \pm 8.68 \mathbf{a b}$ & $4.4 \pm 0.0$ \\
\hline $\mathrm{PC}$ & 3 & $41.62 \pm 0.25 \mathbf{b}$ & $42.70 \pm 0.26 \mathbf{a}$ & $0.25 \pm 0.01 \mathbf{a b}$ & $15.43 \pm 0.27 \mathbf{a b}$ & $8.54 \pm 0.6 \mathbf{a}$ & $0.37 \pm 0.01 \mathbf{a}$ & $1.03 \pm 0.011 \mathrm{a}$ & $169.83 \pm 5.39 \mathbf{a}$ & $3.8 \pm 0.0$ \\
\hline WD & 5 & $48.83 \pm 1.10 \mathbf{a}$ & $37.34 \pm 0.67 \mathbf{b}$ & $0.18 \pm 0.01 \mathbf{b}$ & $13.65 \pm 0.50 \mathbf{b}$ & $1.77 \pm 0.41 \mathbf{b}$ & $0.28 \pm 0.01 \mathbf{b}$ & $0.77 \pm 0.032 \mathbf{b}$ & $272.27 \pm 17.06 \mathbf{b}$ & $4.3 \pm 0.0$ \\
\hline \multicolumn{11}{|l|}{ Uncharred } \\
\hline Bark & 3 & $35.20 \pm 0.12 \mathbf{a}$ & $44.46 \pm 0.22 \mathbf{a}$ & $0.20 \pm 0.01 \mathbf{a}$ & $20.14 \pm 0.30 \mathbf{a b}$ & $1.39 \pm 0.12 \mathbf{a}$ & $0.57 \pm 0.01 \mathbf{a}$ & $1.26 \pm 0.01 \mathbf{a}$ & $175.87 \pm 7.17 \mathbf{a b}$ & $3.7 \pm 0.0$ \\
\hline Pine cones & 3 & $32.14 \pm 0.05 \mathbf{b}$ & $47.97 \pm 0.15 \mathbf{b}$ & $0.27 \pm 0.00 \mathbf{b}$ & $19.62 \pm 0.11 \mathbf{a}$ & $1.02 \pm 0.18 \mathbf{a}$ & $0.61 \pm 0.00 \mathbf{a}$ & $1.49 \pm 0.01 \mathbf{b}$ & $118.53 \pm 1.42 \mathbf{b}$ & $3.5 \pm 0.0$ \\
\hline Woody debris & 5 & $30.85 \pm 0.22 \mathbf{c}$ & $48.24 \pm 0.14 \mathbf{b}$ & $0.15 \pm 0.01 \mathbf{c}$ & $20.76 \pm 0.23 \mathbf{b}$ & $1.00 \pm 0.13 \mathbf{a}$ & $0.67 \pm 0.01 \mathbf{b}$ & $1.56 \pm 0.01 \mathbf{c}$ & $219.67 \pm 20.89 \mathbf{a}$ & $3.7 \pm 0.0$ \\
\hline
\end{tabular}

Lower case letters indicate significant differences within column by category (charred, uncharred) $(p<0.05$, ANOVA, after Tukey-Kramer correction). An * indicates that the uncharred material was used as a covariate when analyzing the charred material. 


\subsection{Incubations}

\subsection{1. $\mathrm{CO}_{2}$ Flux (in Terms of Soil-C)}

To compare differences in soil respiration rates between treatments we investigated the amount of $\mathrm{CO}_{2}$ produced per $\mathrm{g}$ of soil-C per day $\left(\mu \mathrm{g} \mathrm{CO} \mathrm{CO}_{2}\right.$ soil- $\mathrm{C}^{-1}$ day ${ }^{-1}$, Figure $\left.3 \mathrm{~A}\right)$ in order to account for the different amount of $\mathrm{C}$ added to each treatment. Throughout the 60 days of the incubation, the control samples produced more $\mathrm{CO}_{2}$ than each of the wildfire PyC treatments at all time points (Figure 3A, Table 2, and Table S1). Specifically, the control samples produced $6 \%-54 \%$ more $\mathrm{CO}_{2}$ than the soils amended with wildfire $\mathrm{PyC}$ at a given time point. Overall soils amended with low wildfire PyC concentrations produced more $\mathrm{CO}_{2}$ than soils amended with high wildfire PyC concentrations. Also, at all time points soils amended with PC produced more $\mathrm{CO}_{2}$ than soils with $\mathrm{BK}$ or WD, irrespective of concentration. Specifically, soils with low concentrations of PC produced $7 \%-19 \%$ and $11 \%-18 \%$ more $\mathrm{CO}_{2}$ than soils with $\mathrm{BK}$ or WD, respectively. Soils with low concentrations of BK or WD produced similar amounts of $\mathrm{CO}_{2}$. However, at high wildfire $\mathrm{PyC}$ concentrations, soils with WD produced $20 \%-48 \%$ more $\mathrm{CO}_{2}$ than soils with BK. Soils amended with high concentrations of BK produced $28 \%-62 \%$ less $\mathrm{CO}_{2}$ than soils amended with low concentrations of BK.

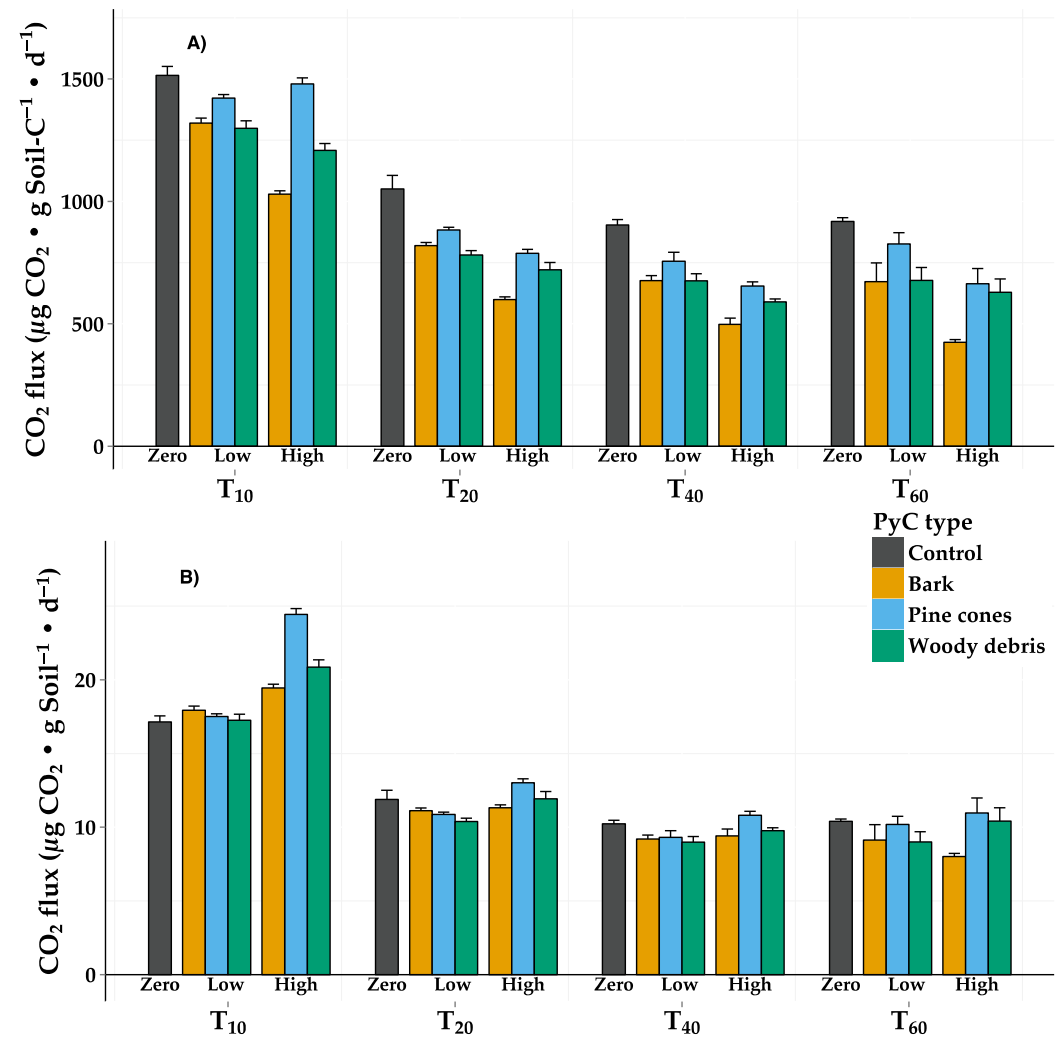

Figure 3. $\mathrm{CO}_{2}$ flux, in terms of $(\mathbf{A}) \mathrm{g}$ soil $\mathrm{C}$ per day and (B) $\mathrm{g}$ soil per day, of soils incubated with charred bark (yellow), charred pine cones (blue), or charred woody debris (green) at zero (black, control), low $(0.1 \%)$, or high (1.0\%) PyC concentrations. The $\mathrm{CO}_{2}$ concentrations were measured on days 10, 20, 40, and 60 ( $\mathrm{T}_{10}, \mathrm{~T}_{20}, \mathrm{~T}_{40}, \mathrm{~T}_{60}$, respectively). The error bars represent one standard error. Results from means separation tests are reported in Table $\mathrm{S} 1$. 
Table 2. Table of F-statistics and $p$-values for ANOVAs of soil respiration for treatment, time, and treatment $\times$ time. All PyC types and concentrations fall under treatment.

\begin{tabular}{cccc}
\hline & Main Effect & F Value & $\boldsymbol{p}$ Value \\
\hline$\mu \mathrm{g} \mathrm{CO}_{2} \mathrm{~g} \mathrm{soil-C}^{-1}$ day $^{-1}$ & Treatment & 56.28 & $<0.0001$ \\
& Time & 1179.68 & $<0.0001$ \\
& Treatment $\times$ Time & 4.07 & $<0.0001$ \\
\hline$\mu \mathrm{g} \mathrm{CO}_{2}$ g soil $^{-1}$ day $^{-1}$ & Treatment & 14.80 & $<0.0001$ \\
& Time & 1546.33 & $<0.0001$ \\
& Treatment $\times$ Time & 14.55 & $<0.0001$ \\
\hline
\end{tabular}

\subsection{2. $\mathrm{CO}_{2}$ Flux (in Terms of g Soil)}

At the beginning $\left(\mathrm{T}_{10}\right)$ of the incubation the control soils produced $2 \%-42 \%$ less $\mathrm{CO}_{2}$ than any soils amended with wildfire $\mathrm{PyC}\left(\mu \mathrm{g} \mathrm{CO} \mathrm{Coil}^{-1} \mathrm{day}^{-1}\right.$, Figure 3B). However, the control soils produced more $\mathrm{CO}_{2}$, in terms of $\mu \mathrm{g} \mathrm{CO}_{2}$ soil $^{-1}$ day $^{-1}$, than soils amended with low concentrations of wildfire PyC at all later time points $\left(\mathrm{T}_{20}-\mathrm{T}_{60}\right.$, Figure $\left.3 \mathrm{~B}\right)$. Specifically, the control soils produced $6 \%-22 \%$, $2 \%-50 \%$, and $12 \%-63 \%$ more $\mathrm{CO}_{2}$ than soils amended with low concentrations of $\mathrm{BK}, \mathrm{PC}$, and WD, respectively. Soils amended with high concentrations of PC and WD produced $7 \%-28 \%$ and $6 \%-17 \%$ (respectively) more $\mathrm{CO}_{2}$ than soils with low concentrations of $\mathrm{PC}$ and $\mathrm{WD}$ at all time points expect $\mathrm{T}_{10}$ (Figure 3B and Table S2).

\subsubsection{Nitrogen Flux}

At the beginning of the incubation, soils with low concentrations of wildfire PyC had greater $\mathrm{N}$ mineralization rates than soils with high concentrations of wildfire PyC (Figure 4, Table 2). Specifically, soils with low concentrations of BK, PC, and WD had 23\%, 50\%, and 37\% higher N mineralization rates, respectively, than soils with high concentrations (Figure 4, Tables 3 and 4). Of the soils with high concentrations of wildfire $\mathrm{PyC}$, soils with $\mathrm{BK}$ had the greatest $\mathrm{N}$ mineralization rates at all time points $\left(26 \%, 15 \%, 20 \%\right.$ at $\mathrm{T}_{20}, \mathrm{~T}_{40}, \mathrm{~T}_{60}$, respectively). At $\mathrm{T}_{20}$ and $\mathrm{T}_{40}$ the soils with low concentrations of wildfire $\mathrm{PyC}$ had $17 \%$ and $60 \%$ higher $\mathrm{N}$ mineralization rates than the control soils. However, at $\mathrm{T}_{60}$ the $\mathrm{N}$ mineralization rates of the control soils were $8 \%-60 \%$ greater than all wildfire PyC treatments (Figure 4, Table 2). 

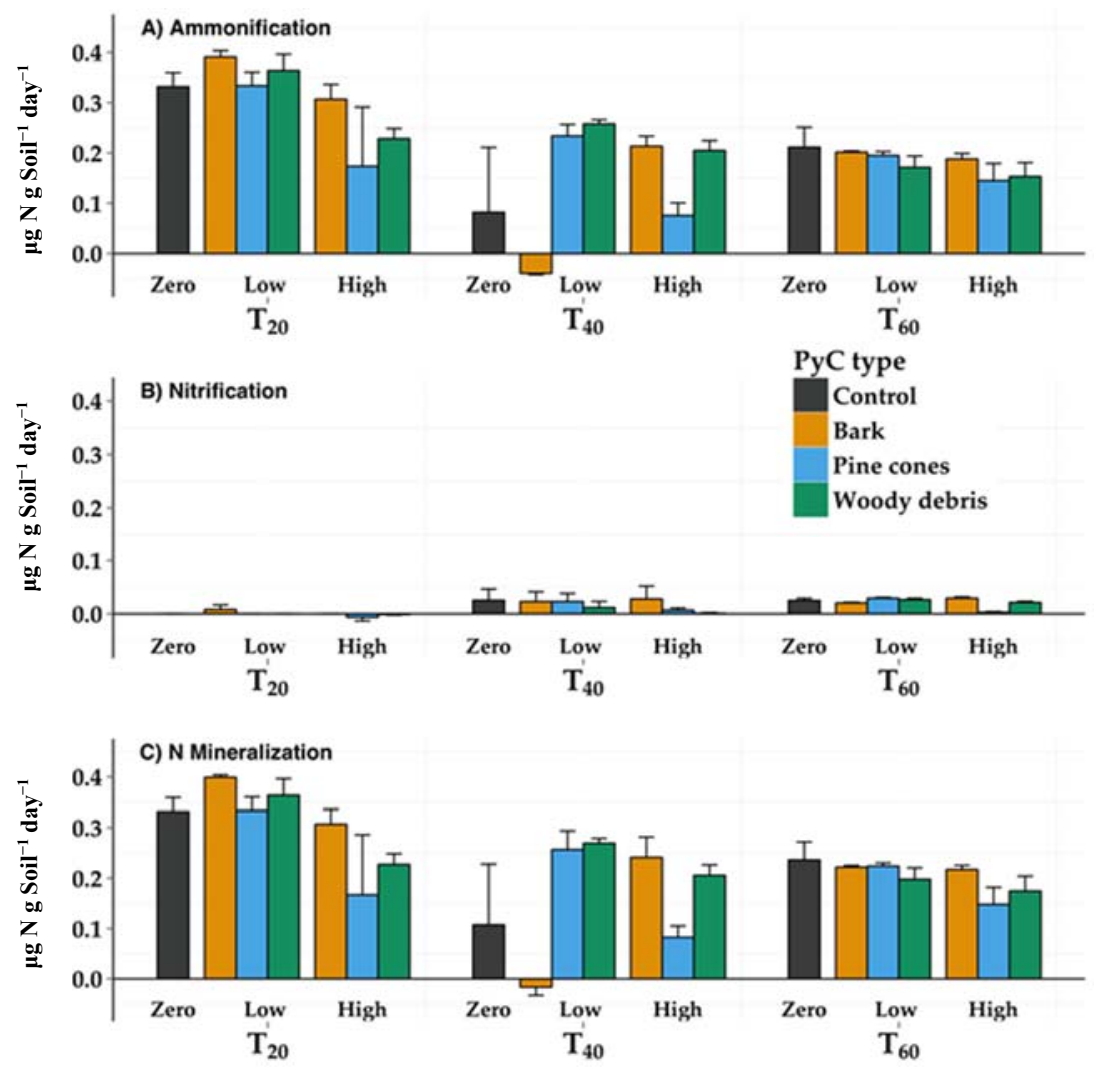

Figure 4. (A) Ammonification rate, $(\mathbf{B})$ nitrification rate, and $(\mathbf{C})$ total $\mathrm{N}$ mineralization rate of soils incubated with charred bark (yellow), charred pine cones (blue), or charred woody debris (green) at either zero (black, control), low $(0.1 \%)$, or high $(1.0 \%)$ PyC concentrations. The soils were incubated for 20, 40, 60 days ( $\mathrm{T}_{20}, \mathrm{~T}_{40}, \mathrm{~T}_{60}$, respectively). The error bars represent one standard error.

Table 3. Summary table of means \pm standard errors (one standard error) for $\mathrm{N}$ mineralization

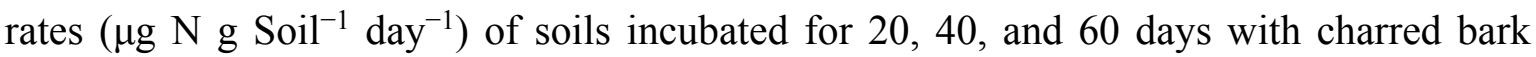
(BK), charred pine cones (PC), or charred woody debris (WD) at zero (control), low $(0.1 \%)$, or high $(1.0 \%)$ PyC concentrations.

\begin{tabular}{cccccc}
\hline \multicolumn{7}{c}{ PyC Type } & & & \\
\hline Time & Concentration & Control & BK & PC & WD \\
\hline 20 & Zero & $0.33 \pm 0.03 \mathbf{c}$ & - & - & - \\
& Low & - & $0.40 \pm 0.01 \mathbf{d}$ & $0.33 \pm 0.03 \mathbf{c}$ & $0.36 \pm 0.03 \mathbf{c d}$ \\
& High & - & $0.31 \pm 0.03 \mathbf{b c}$ & $0.17 \pm 0.12 \mathbf{a b c}$ & $0.23 \pm 0.02 \mathbf{b c}$ \\
40 & Zero & $0.11 \pm 0.12 \mathbf{a b c}$ & - & - & - \\
& Low & - & $-0.17 \pm 0.16 \mathbf{a}$ & $0.26 \pm 0.04 \mathbf{b c}$ & $0.27 \pm 0.01 \mathbf{b c}$ \\
& High & - & $0.24 \pm 0.04 \mathbf{b c}$ & $0.08 \pm 0.02 \mathbf{~ a b}$ & $0.21 \pm 0.02 \mathbf{~ a b c}$ \\
& Zero & $0.24 \pm 0.04 \mathbf{b c}$ & - & - & - \\
& Low & - & $0.22 \pm 0.00 \mathbf{b c}$ & $0.22 \pm 0.01 \mathbf{b c}$ & $0.20 \pm 0.02 \mathbf{~ a b c}$ \\
& High & - & $0.22 \pm 0.01 \mathbf{a b c}$ & $0.15 \pm 0.03 \mathbf{~ a b c}$ & $0.18 \pm 0.03 \mathbf{~ a b c}$ \\
\hline
\end{tabular}

Significant differences among all time, concentration and PyC type comparisons are indicated by letters next to each mean $(p<0.05$, ANOVA). Treatment combinations that did not exist (i.e. soils with zero concentration of $\mathrm{BK}$, which were functionally equivalent to the Control are indicated by - 
Table 4. Table of F-statistics and $p$-values for ANOVAs of ammonification, nitrification, and $\mathrm{N}$ mineralization for treatment, time, and treatment $\times$ time. All PyC type and concentrations fall under treatment.

\begin{tabular}{cccc}
\hline & Main Effect & F Value & $\boldsymbol{p}$ Value \\
\hline Ammonification & Treatment & 3.26 & 0.0101 \\
& Time & 24.77 & $<0.0001$ \\
& Treatment $\times$ Time & 3.15 & 0.0029 \\
\hline Nitrification & Treatment & 1.47 & 0.2108 \\
& Time & 10.22 & 0.0002 \\
& Treatment $\times$ Time & 0.43 & 0.9437 \\
\hline \multirow{2}{*}{ N mineralization } & Treatment & 3.96 & 0.0032 \\
& Time & 18.94 & $<0.0001$ \\
& Treatment $\times$ Time & 2.95 & 0.0047 \\
\hline
\end{tabular}

All PyC type and concentrations fall under treatment.

\section{Discussion}

Our research provides an assessment of variability in naturally produced $\mathrm{PyC}$ collected from a high-severity wildfire in jack pine forest in Michigan. Our use of naturally aged PyC (2 years post-fire) provides information on intermediate-term PyC effects on soil processes rather than short-term effects that result from transient chemical properties [24,33], or long-term effects of PyC $>100$ years old, which over time becomes heavily occluded by senescent fungal hyphae and humic debris [11]. The addition of all types and concentrations of wildfire $\mathrm{PyC}$ to soil increased $\mathrm{N}$ mineralization rates when compared to the control samples. This finding is consistent with Deluca, et al. [10], who found that charred wood PyC increased nitrification in ponderosa pine forest soils. This increase in $\mathrm{N}$ mineralization rates indicates an increase in microbial activity. Microbial abundance has been found to increase with the addition of experimental PyC from wood [3,4]. Increases in microbial abundance may be due to the physical and chemical characteristics of PyC. For example, PyC may increase soil moisture, provide microhabitats for some microbial communities, and increase the $\mathrm{pH}$ of soil [4]. Although we did not measure microbial communities, we found that all types of PyC we used had a lower $\mathrm{pH}$ than the un-amended soil. Thus, two year old PyC in our jack pine forests may decrease $\mathrm{pH}$ in sandy soils. In contrast, other studies have shown that PyC may have a liming potential and may buffer acidic soils, thereby increasing $\mathrm{pH}$ and facilitating an increase in microbial abundance [4]. These contrasting results further suggest that the type of PyC incorporated into soil has an important effect on soil processes. It is possible that the increase in $\mathrm{N}$ mineralization we observed may have been influenced by changes in microbial abundance, which may increase due to release of nutrients from experimental PyC [3].

We observed a decrease in soil respiration in terms of $\mu \mathrm{g} \mathrm{CO}_{2} \mathrm{~g} \mathrm{soil}^{-1}$ day $^{-1}$, compared to the control soils, when low concentrations of all PyC types were added to soils except at $\mathrm{T}_{10}$ (Figure 3B). However, soils with high concentrations of $\mathrm{PC}$ produced more $\mathrm{CO}_{2}$ than the control soils (Figure 3B). In order to accurately represent the fact that there were different amounts of $\mathrm{C}$ in the soils due to the addition of PyC, we also evaluated soil respiration in terms of $\mu \mathrm{g} \mathrm{CO}_{2} \mathrm{~g}_{\text {soil- }} \mathrm{C}^{-1}$ day $^{-1}$ (Figure $3 \mathrm{~A}$ ). We observed a decrease in soil respiration in soils amended with wildfire PyC, which indicates a 
decrease in microbial activity. This decrease in soil respiration may be due to the fact that all wildfire PyC types collected for this study were collected from a site that experienced a high severity crown fire. Zimmerman, et al. [34] found that experimental PyC produced at low temperatures $\left(250-400{ }^{\circ} \mathrm{C}\right)$ increased soil respiration, whereas experimental $\mathrm{PyC}$ produced at high temperatures $\left(525-650{ }^{\circ} \mathrm{C}\right)$ caused decreased soil respiration. Wildfires can have a greater range in temperature than prescribed fires. For example, Hartford and Frandsen [35] found that the litter surface, duff, and soil surface reached 300,515 , and $400{ }^{\circ} \mathrm{C}$, respectively, in a prescribed ground fire in mixed-conifer forests (Larix occidentalis and P. contorta) in western Montana, whereas Santín, et al. [12] found that the mean temperature during an experimental stand-replacing crown fire in a jack pine forest in Canada was $<70{ }^{\circ} \mathrm{C}$ at the mineral soil surface and $750{ }^{\circ} \mathrm{C}$ at the surface of the forest floor. Furthermore, Schneider, et al. [36] in a study of experimental fire in pitch pine (P. rigida Mill) forest in New Jersey, found that temperatures in the canopy can reach $510-650{ }^{\circ} \mathrm{C}$ during a crown fire whereas temperatures in the canopy during surface fire range between 0 and $260{ }^{\circ} \mathrm{C}$. Together, the temperature ranges reported from these experimental fires suggest that the mean temperature at the floor forest during fire in conifer forests may range between 300 and $750{ }^{\circ} \mathrm{C}$ and that the temperature in the canopy may reach $650{ }^{\circ} \mathrm{C}$. Although the study conducted by Santín, et al. [12] also focused on jack pine forest, their study was conducted in the boreal region and their study site supported a deep moss layer and saturated mineral soil. Jack pine forests in our study site are more ecologically similar to the pitch pine forests in the New Jersey, USA pine barrens because both forest types have thin forest floors and are found on dry sandy soils [37]. Therefore, the forest in our study site probably experienced fire temperatures more similar to those reported from crown fire in pitch pine forest in New Jersey.

If wildfire PyC increases microbial activity we would expect to see increases in $\mathrm{N}$ mineralization and soil respiration rates (indices for microbial activity) with the addition of PyC to soils. When comparing $\mathrm{N}$ mineralization rates (Figure 4C) and soil respiration rates (in terms of $\mathrm{g}$ soil, Figure 3B) there was an increase in $\mathrm{N}$ mineralization but a decrease in soil respiration for soils amended with low concentrations of PyC. However, soils amended with high concentrations of PyC had lower $\mathrm{N}$ mineralization rates than the controls but greater soil respiration rates. This opposite response between the two microbial activity indices we used presents a paradox [3]. In some cases, decreases in soil respiration rates may be caused by $\mathrm{CO}_{2}$ precipitating onto high-pH surfaces of PyC [3,7]. However, because our PyC was acidic it is unlikely that this chemical reaction is occurring in our study. Another possible explanation is that the $\mathrm{PyC}$ may be sorbing the $\mathrm{CO}_{2}$ due to its porous structure [7]. This may be occurring in our samples even though our PyC was collected two years post-fire because we ground the $\mathrm{PyC}$, thereby opening new pore spaces and/or surfaces that were previously protected from the atmosphere or interaction with the soil matrix. However, the differences in soil respiration rates among PyC types followed the differences in $\mathrm{pH}$ of the PyC types. PC was the most acidic type of PyC and soils amended with PC had the highest soil respiration rates, whereas BK was the most basic and soils amended with BK had the lowest soil respiration rates (Figure 3). The lower $\mathrm{pH}$ in soils amended with PC may have increased fungal growth and therefore increased soil respiration. This paradox may also result from $\mathrm{PyC}$ increasing microbial $\mathrm{C}$ utilization and thus decreasing the need for enzyme production, as Bailey, et al. [38] observed decreased microbial enzyme activity after the addition of experimental PyC. Although we did not investigate microbial biomass and/or phospholipid fatty acid analysis, this type of information would provide valuable insight on additional indices of microbial 
community composition and activity in future studies. Linking additional information on PyC characteristics (e.g., relative contributions of benzene polycarboxylic acid molecular markers [36]) with its effects on ecosystem processes represents a major knowledge gap. This information would help refine current understanding of fire effects on soil function, and would be relevant for understanding interactions among climate, fire and forest $\mathrm{C}$ dynamics.

Our results show that the magnitude of the effect of wildfire $\mathrm{PyC}$ on soil $\mathrm{C}$ and $\mathrm{N}$ mineralization rates differs among type and concentration of wildfire PyC added to the soil. Of all three types of wildfire PyC, different concentrations of BK had the largest effects on nutrient dynamics in soils. High concentrations of BK added to soils caused a significant decrease in soil respiration. In a study of PyC production in a stand-replacing fire boreal jack pine forest in Canada, Santín, et al. [12] found that one third $\left(1.4 \mathrm{t} \mathrm{ha}^{-1}\right)$ of PyC produced is in the form of BK. Santín, et al. [12] reported similar \% C for charred bark (62.9\%) and similar percent increase in $\mathrm{C}$ due to charring (15.6\%) compared to the $15.0 \%$ change we observed. BK represents a large pool of PyC in jack pine forests, and may be added to soils at high concentration after a fire. However, charred bark can also stay attached to the tree for a few years after a fire (L. Michelotti, personal observation). Thus, there is a need to identify the rate of PyC input to the soil ecosystem over time after a fire as well as how differences among forest types influence the rates of PyC input to soil.

Other researchers have shown that $\mathrm{PyC}$ aromaticity increases with charring temperature $[4,5,15,16,36]$ and have suggested that it may be possible to approximate the relative maximum temperatures experienced by specific source materials during charring $[13,14,36]$. To date, controlled investigation of relationships between combustion conditions and $\mathrm{PyC}$ characteristics have involved prescribed fires or laboratory heating experiments. Interpreting the characteristics of wildfire PyC, or inferring its formation conditions, may be more challenging because combustion conditions in unplanned wildfires remain poorly understood. A laboratory heating experiment using red pine (Pinus resinosa) wood indicated that $\mathrm{C}$ and $\mathrm{N}$ concentrations increased with heating temperature from $70{ }^{\circ} \mathrm{C}$ to $350{ }^{\circ} \mathrm{C}$, whereas $\mathrm{H}$ and $\mathrm{O}$ concentrations decreased [28]. The $\mathrm{C}$ concentration in our WD PyC was similar to the experimental red pine wood $\mathrm{PyC}$ produced at the lowest temperatures, whereas our $\mathrm{H}$ concentrations were greater than the lowest-temperature experimental $\mathrm{PyC}$ and our $\mathrm{O}$ concentrations were much lower than those reported for the highest-temperature experimental PyC [28] The differences in the elemental concentrations of our wildfire-produced PyC relative to those reported for experimentally charred red pine wood highlights the potential danger of inferring wildfire-produced PyC characteristics from experimental studies, and also highlights a major need for information to characterize variability in wildfire-produced PyC. Although BK and WD in our study exhibited different chemical characteristics than $\mathrm{PC}$, we are unable to confidently assume that these characteristics resulted from more similar charring temperatures to each other than to PC (Table 1). However, our PyC types fall under different portions of the PyC continuum [39]. Specifically, BK and WD have an H/C (0.66 and 0.77 , respectively) similar to black carbon whereas PC has $\mathrm{H} / \mathrm{C}$ that is similar to partly charred biomass [40]. However, the soils we amended with PC had greater soil respiration rates than soils amended with the other wildfire PyC types, and soil respiration has been found to decrease as charring temperature of experimental PyC increases [8]. Together, our results suggest that differences in source material influence wildfire PyC physical and chemical characteristics 
and the resulting effects on nutrient dynamics. We emphasize that additional research is needed to differentiate between the effects of temperature and source material in wildfire PyC.

Changes in fire frequency, severity or seasonality have occurred or are anticipated to occur as a result of climate change in many parts of the world. For example, increased occurrence of drought and increased fire season length can both contribute to increased fire frequency [1,2]. Increased wildfire activity will result in more $\mathrm{CO}_{2}$ released to the atmosphere by fires and an increase in the overall strength of fires as a net $\mathrm{C}$ source [41]. Santín, et al. [12] reported that $4.8 \mathrm{t} \mathrm{ha}^{-1} \mathrm{PyC}$ were produced in a stand-replacing fire in boreal jack pine forest, whereas DeLuca and Aplet [42] estimated that $0.18-1.84 \mathrm{tha}^{-1}$ and $0.34-3.36 \mathrm{t} \mathrm{ha}^{-1}$ were produced in wildfires in ponderosa pine and lodgepole pine forests, respectively, in the western U.S. Together, these studies show that the total mass of PyC differs among forest type - which encompasses differences in fire regime, elevation and/or climate, and aboveground biomass - and that the ecologically similar jack pine and lodgepole pine forests reflect both high-severity fire and the upper end of aboveground PyC mass estimates that are available to date. We focused on wildfire in jack pine forest as an example study system for investigating how the production of $\mathrm{PyC}$ in high severity fires may affect post-fire nutrient dynamics.

It is reasonable to expect that changes in fire frequency, season, size and severity that result from changes in regional to global climate would also lead to changes in combustion conditions relative to historic fire conditions that would in turn influence PyC formation rates and characteristics. In our study area, high-severity fire in jack pine forest results in bark that is charred from the base to top of standing trees [43]. If forests that historically experienced lower-severity fires (e.g., surface fires) undergo shifts in disturbance regimes to include high-severity fire (e.g., canopy fire) as is already the case in many forests of the western U.S. [20,21,44,45], we suggest that a greater proportion of the aboveground forest may be converted to PyC. Although it has been suggested the PyC produced during a fire may be consumed in subsequent fires [46], recent studies have found limited PyC consumption in subsequent fires [47,48]. Thus, the effects of climate change on fire regimes may lead to increased PyC stocks produced in each forest fire. However, decreases or no change in fire severity in response to climate change may also occur, depending on forest biome [49]. Our results in terms of $\mu \mathrm{g} \mathrm{CO}_{2} \mathrm{~g}$ soil- $\mathrm{C}^{-1}$ day $^{-1}$ suggest that PyC may decrease $\mathrm{C}$ flux from soils, and that this effect is influenced by the concentration of $\mathrm{PyC}$ in soil. High concentrations of wildfire PyC that become incorporated into the mineral soil over the longer term after fire may actually decrease $\mathrm{C}$ flux from the soil to the atmosphere. We note that vegetation recovery also has an important influence on post-fire $\mathrm{C}$ dynamics [50,51], and is not addressed by our study.

\section{Conclusions}

Our data showed that differences in wildfire PyC source material and concentration in soil influence post-fire nutrient dynamics. The availability of wildfire fuels across broad geographical regions is predicted to increase due to greater frequency of droughts [2]. Wider ranges in types of wildfire fuels may lead to greater variation in PyC characteristics produced during wildfire, as more types of forest fuels will be available for combustion and pyrolysis. Our study indicates that wildfire PyC produced from different tissues of a single tree species causes significant variation in nutrient dynamics in soil. It is likely that there is even greater variation in $\mathrm{PyC}$ produced from different tree and 
understory species in mixed-species or multi-age forests. Therefore, an understanding of how PyC differs by species and source material type is necessary to elucidate how variability in wildfire PyC affects post-fire nutrient dynamics. Our study provides support for addressing the contributions of particular types and concentrations of $\mathrm{PyC}$ added to soils from wildfires in order to accurately understand the impact of wildfire on post-fire forest $\mathrm{C}$ budgets.

\section{Acknowledgments}

This research was conducted on public land owned by the Michigan DNR under a research permit issued to J. Miesel. Funding for this study was provided by Michigan State University. We thank D. $\mathrm{Lu}$ and A. Meier for field assistance, J. Huck for laboratory assistance, S. Grand for statistical advice, F. Santos, B. Maestrini, and B. Sulman for helpful discussion of the manuscript, and A. Meier for editorial comments. The manuscript was improved by the helpful comments of two anonymous reviewers.

\section{Author Contributions}

Lucas A. Michelotti developed the research design, collected the data, and led the interpretation of the results, figure generation, and manuscript writing. Jessica R. Miesel provided assistance with the research design, data collection and interpretation, and writing.

\section{Conflicts of Interest}

The authors declare no conflict of interest.

\section{References}

1. Pechony, O.; Shindell, D.T. Driving forces of global wildfires over the past millennium and the forthcoming century. Proc. Natl. Acad. Sci. USA 2010, 107, 19167-19170.

2. Van Mantgem, P.J.; Nesmith, J.C.; Keifer, M.; Knapp, E.E.; Flint, A.; Flint, L. Climatic stress increases forest fire severity across the western United States. Ecol. Lett. 2013, 16, 1151-1156.

3. Lehmann, J.; Rillig, M.C.; Thies, J.; Masiello, C.A.; Hockaday, W.C.; Crowley, D. Biochar effects on soil biota-A review. Soil Biol. Biochem. 2011, 43, 1812-1836.

4. Ameloot, N.; Graber, E.R.; Verheijen, F.G.A.; De Neve, S. Interactions between biochar stability and soil organisms: Review and research needs. Eur. J. Soil Sci. 2013, 64, 379-390.

5. Schmidt, M.W.I.; Noack, A.G. Black carbon in soils and sediments: Analysis, distribution, implications, and current challenges. Global Biogeochem. Cy. 2000, 14, 777-793.

6. Norwood, M.J.; Louchouarn, P.; Kuo, L.J.; Harvey, O.R. Characterization and biodegradation of water-soluble biomarkers and organic carbon extracted from low temperature chars. Org. Geochem. 2013, 56, 111-119.

7. Maestrini, B.; Nannipieri, P.; Abiven, S. A meta-analysis on pyrogenic organic matter induced priming effect. GCB Bioenerg. 2014, doi:10.1111/gcbb.12194.

8. Zimmerman, A.R. Abiotic and microbial oxidation of laboratory-produced black carbon (biochar). Environ. Sci. Technol. 2010, 44, 1295-1301. 
9. Knicker, H. How does fire affect the nature and stability of soil organic nitrogen and carbon? A review. Biogeochemistry 2007, 85, 91-118.

10. DeLuca, T.H.; MacKenzie, M.D.; Gundale, M.J.; Holben, W.E. Wildfire-produced charcoal directly influences nitrogen cycling in ponderosa pine forests. Soil Sci. Soc. Am. J. 2006, 70, 448-453.

11. Zackrisson, O.; Nilsson, M.C.; Wardle, D.A. Key ecological function of charcoal from wildfire in the boreal forest. Oikos 1996, 77, 10-19.

12. Santín, C.; Doerr, S.H.; Preston, C.M.; González-Rodríguez, G. Pyrogenic organic matter production from wildfires: A missing sink in the global carbon cycle. Glob. Chang. Biol. 2015, $21,1621-1633$.

13. Soucémarianadin, L.N.; Quideau, S.A.; MacKenzie, M.D.; Bernard, G.M.; Wasylishen, R.E. Laboratory charring conditions affect black carbon properties: A case study from quebec black spruce forests. Org. Geochem. 2013, 62, 46-55.

14. Preston, C.M.; Schmidt, M.W.I. Black (pyrogenic) carbon: A synthesis of current knowledge and uncertainties with special consideration of boreal regions. Biogeosciences 2006, 3, 397-420.

15. McBeath, A.V.; Smernik, R.J. Variation in the degree of aromatic condensation of chars. Org. Geochem. 2009, 40, 1161-1168.

16. McBeath, A.V.; Smernik, R.J.; Schneider, M.P.W.; Schmidt, M.W.I.; Plant, E.L. Determination of the aromaticity and the degree of aromatic condensation of a thermosequence of wood charcoal using NMR. Org. Geochem. 2011, 42, 1194-1202.

17. Lehmann, J.; Abiven, S.; Kleber, M.; Pan, G.; Singh, B.P.; Sohi, S.P.; Zimmerman, A.R. Persistence of biochar in soil. In Biochar for Environmental Management: Science, Technology and Implementation, 2nd ed.; Lehmann, J., Joseph, S., Eds.; Earthscan: London, UK, 2015; pp. 233-280.

18. McBeath, A.V.; Smernik, R.J.; Krull, E.S. A demonstration of the high variability of chars produced from wood in bushfires. Org. Geochem. 2013, 55, 38-44.

19. Simard, A.J.; Blank., R.W. Fire history of a Michigan jack pine forest. Mich. Acad. 1982 15, 59-71.

20. Hammond, J.; Shackley, S.; Prendergast-Miller, M.; Cook, J.; Buckingham, S.; Pappa, V.A. Biochar field testing in the UK: Outcomes and implications for use. Carbon Manag. 2013, 4, 159-170.

21. Miller, J.D.; Safford, H. Trends in wildfire severity: 1984 to2010 in the Sierra Nevada, Modoc Plateau, and southern cascades, California, USA. Fire Ecol. 2012, 8, 41-57.

22. NOAA. National Climatic Data Center. Available online: http://www.ncdc.noaa.gov (accessed on 22 March 2015).

23. Werlein, J.O. Soil Survey of Crawford County, Michigan; USDA Natural Resources Conservation Service and USDA Forest Service: Washington, DC, USA, 1998; p. 274.

24. Abiven, S.; Hengartner, P.; Schneider, M.P.W.; Singh, N.; Schmidt, M.W.I. Pyrogenic carbon soluble fraction is larger and more aromatic in aged charcoal than in fresh charcoal. Soil Biol. Biochem. 2011, 43, 1615-1617. 
25. Castaldi, S.; Riondino, M.; Baronti, S.; Esposito, F.R.; Marzaioli, R.; Rutigliano, F.A.; Vaccari, F.P.; Miglietta, F. Impact of biochar application to a mediterranean wheat crop on soil microbial activity and greenhouse gas fluxes. Chemosphere 2011, 85, 1464-1471.

26. ASTM E1755-01. Standard method for the determination of ash in biomass. In 2003 Annual Book of ASTM Standards, Volume 11.05; American Society for Testing and Materials International: West Conshohocken, PA, USA, 2007; Volume 1.

27. Knicker, H.; Hilscher, A.; Gonzalez-Vila, F.J.; Almendros, G. A new conceptual model for the structural properties of char produced during vegetation fires. Org. Geochem. 2008, 39, 935-939.

28. Baldock, J.A.; Smernik, R.J. Chemical composition and bioavailability of thermally, altered pinus resinosa (red pine) wood. Org. Geochem. 2002, 33, 1093-1109.

29. Robertson, G.P.; Coleman, D.C.; Bledsoe, C.S.; Sollins, P. Standard Soil Methods for Long-Term Ecological Research; Oxford University Press: Oxford, UK, 1999.

30. Sinsabaugh, R.L.; Reynolds, H.; Long, T.M. Rapid assay for amidohydrolase (urease) activity in environmental samples. Soil. Biol. Biochem. 2000, 32, 2095-2097.

31. Doane, T.A.; Horwath, W.R. Spectrophotometric determination of nitrate with a single reagent. Anal. Lett. 2003, 36, 2713-2722.

32. Wiedemeier, D.B.; Abiven, S.; Hockaday, W.C.; Keiluweit, M.; Kleber, M.; Masiello, C.A.; McBeath, A.V.; Nico, P.S.; Pyle, L.A.; Schneider, M.P.W., et al. Aromaticity and degree of aromatic condensation of char. Org. Geochem. 2015, 78, 135-143.

33. Chan, K.Y.; Xu, Z. Biochar: Nutrient properties and their enhancement. In Biochar for Environmental Management: Science, Technology and Implementation; Lehmann, J., Joseph, S., Eds. Earthscan: London, UK, 2009; pp. 67-84.

34. Zimmerman, A.R.; Gao, B.; Ahn, M.Y. Positive and negative carbon mineralization priming effects among a variety of biochar-amended soils. Soil Biol. Biochem. 2011, 43, 1169-1179.

35. Hartford, R.A.; Frandsen, W.H. When it's hot, it's hot... or maybe it's not! (surface flaming may not portend extensive soil heating). Inter. J. Wildland Fire 1992, 2, 139-144.

36. Schneider, M.P.; Pyle, L.A.; Clark, K.L.; Hockaday, W.C.; Masiello, C.A.; Schmidt, M.W. Toward a "molecular thermometer" to estimate the charring temperature of wildland charcoals derived from different biomass sources. Environ. Sci. Techn. 2013, 47, 11490-11495.

37. Gucker, C.L. Pinus rigida. In Fire Effects Information System; USDA Forest Service, Rocky mountain Research Station, Fire Science Laboratory (Producer), USA, 2007. Available Online: http://www.fs.fed.us/database/feis/plants/tree/pinrig/all.html (accessed on 2 April 2015).

38. Bailey, V.L.; Fansler, S.J.; Smith, J.L.; Bolton, H. Reconciling apparent variability in effects of biochar amendment on soil enzyme activities by assay optimization. Soil Biol. Biochem. 2011, 43, 296-301.

39. Masiello, C.A. New directions in black carbon organic geochemistry. Mar. Chem. 2004, 92, 201-213.

40. Bird, M.I.; Ascough, P.L. Isotopes in pyrogenic carbon: A review. Org. Geochem. 2012, 42, 1529-1539.

41. Stocker, T.; Qin, D.; Plattner, G.; Tignor, M.; Allen, S.; Boschung, J.; Nauels, A.; Xia, Y.; Bex, B.; Midgley, B. Climate Change 2013: The Physical Science Basis; Cambridge University Press: Cambridge, UK; New York, NY, USA, 2014. 
42. DeLuca, T.H.; Aplet, G.H. Charcoal and carbon storage in forest soils of the Rocky Mountain west. Front. Ecol. Environ. 2008, 6, 18-24.

43. Michelotti, L.A.; Miesel, J.R. Quantification of above and belowground pyrogenic carbon stocks in a jack pine wildfire chronosequence. Unpublished work, 2015.

44. Taylor, A.H.; Skinner, C.N. Fire history and landscape dynamics in a late-successional reserve, Klamath Mountains, California, USA. Forest Ecol. Manag. 1998, 111, 285-301.

45. Wright, C.S.; Agee, J.K. Fire and vegetation history in the eastern Cascade Mountains, Washington. Ecol. Applic. 2004, 14, 443-459.

46. Bird, M.I.; Wynn, J.G.; Saiz, G.; Wurster, C.M.; McBeath, A. The pyrogenic carbon cycle. Earth Planet. Sci. 2014, 43, doi:10.1146/annurev-earth-060614-105038.

47. Santín, C.; Doerr, S.; Preston, C.; Bryant, R. Consumption of residual pyrogenic carbon by wildfire. Intern. J. Wildland Fire 2013, 22, 1072-1077.

48. Saiz, G.; Wynn, J.; Wurster, C.; Goodrick, I.; Nelson, P.; Bird, M. Pyrogenic carbon from tropical savanna burning: Production and stable isotope composition. Biogeosciences 2014, 11, 15149-15183.

49. Amiro, B.D.; Cantin, A.; Flannigan, M.D.; de Groot, W.J. Future emissions from canadian boreal forest fires. Can. J. Forest Res. 2009, 39, 383-395.

50. Hart, S.C.; DeLuca, T.H.; Newman, G.S.; MacKenzie, M.D.; Boyle, S.I. Post-fire vegetative dynamics as drivers of microbial community structure and function in forest soils. Forest Ecol. Manag. 2005, 220, 166-184.

51. Kashian, D.M.; Romme, W.H.; Tinker, D.B.; Turner, M.G.; Ryan, M.G. Carbon storage on landscapes with stand-replacing fires. BioScience 2006, 56, 598-606.

(C) 2015 by the authors; licensee MDPI, Basel, Switzerland. This article is an open access article distributed under the terms and conditions of the Creative Commons Attribution license (http://creativecommons.org/licenses/by/4.0/). 